\title{
Visual-commercial discourses of infants in direct marketing sent to first-time parents
}

\author{
Johanna Sjöberg
}

\section{Linköping University Post Print}

\section{Tweet}

N.B.: When citing this work, cite the original article.

Original Publication:

Johanna Sjöberg, Visual-commercial discourses of infants in direct marketing sent to first-time parents, 2015, Young Consumers, (16), 2, 107-140.

http://dx.doi.org/10.1108/YC-08-2014-00465

Copyright: Emerald Group Publishing Limited

http://www.emeraldinsight.com/

Postprint available at: Linköping University Electronic Press

http://urn.kb.se/resolve?urn=urn:nbn:se:liu:diva-121460 


\section{Visual-commercial discourses of infants in direct marketing sent to first-time parents}

\section{Introduction}

The very youngest children are practically invisible in childhood studies (Lupton, 2012; McNamee and Seymour, 2013). Moreover, they receive very little scholarly attention from researchers in the field of consumer culture. This is the case despite the fact that family life and family consumption are being formed during the period when children are very young (Martens, 2010). How infants are made part of consumer culture and how they are understood as actors in family consumption are therefore an important but rarely investigated area. Direct marketing concerning child consumption is also a neglected field of investigation (with the exception of Sjöberg, 2012), yet it is something most families in the West meet in their everyday life.

According to marketing practitioners, one of the advantages of addressed marketing is that, given its targeting of a predefined group, it can be more complex than, for example, print ads. Another advantage mentioned is that the dispatches can be enormously varied in design and content (Dahlqvist, U. and Linde, M., 2009; Bonde-Teir, M. and Westerståhl, 2005). The latter means several booklets, leaflets, free samples and so on can be sent in one dispatch. When many companies target families at the same time a great deal of material are received in the everyday life. In comparison with for example TV commercials or digital advertising this is physical objects that are laying about in the home, easy to look at and interact with again and again, until someone decides to put it in the trash bin.

In a schematic separation of privacy and home life, on the one hand, and public places made for consumption, on the other, one can easily consider the home a consumption-free zone. However such a division between the private and the public, between consumption and nonconsumption is imaginary. Everyday life, within and outside the home, is permeated by consumer practices (Svensson, 1988; Grusell, 2008). Moreover, consumption is not only a matter of money and commodity exchange. Rather consumption can be seen as a larger process in which consumption of commodities, services, places and experiences takes place long before and long after the actual purchase. Strolling through a store or engaging with advertisements at home are therefore also forms of consumption, regardless of whether or not it leads to purchases (Mackay, 1997; Paterson, 2006; Husz and Lagerkvist, 2001). Consumption, media and images are furthermore amalgamated to such an extent that the role as a consumer and the role as a viewer are more or less identical (Jansson, 2002). Advertising is therefore not to be seen as something only communicating information about products, but as a product in itself (Goldman, 1992). According to Schroeder (2002), it is a form of visual consumption, both being consumed with the eyes and (made to) engage people economically in the sphere of consumption. This means that the direct marketing reaching families through the mailbox at home represents one of the most ordinary consumer practices.

Direct marketing sent to new parents at the time when the child is very young connects parents and infants as consumers in interesting ways. Direct marketing is sent to and addresses parents who are interesting for companies because of their new identity as parents, an identity they have acquired through the existence of the newborn. The commodities are promoted to parents, to be bought by them but often to be used by or for the child. Parsons and Ballantine (2008) show that, in decision-making regarding gifts to children, notions of children's characteristics and personality are vital in determining what is eventually bought and given. This means that ideas about what children are are central in consumption for children. Because infants, in contrast to most other children, cannot express what they want, consumer decisions concerning them stem completely from parents' ideas about what the infant needs (and wants) and in the end about what infants are. As direct marketing is sent to new parents very early on, it has the potential to orientate and socialize them into parenthood and to function as a source for making meaning in relation to infants. The present study, therefore, focuses on the notions 
of infants presented in direct marketing sent to people who have recently become parents and scrutinizes how infants are being and becoming part of consumer culture and being and becoming consumers through the visuality of direct marketing.

The article discusses three dominating discourses of infants articulated in addressed direct marketing sent to three families in Sweden, during the first year after the birth of their first child. The purpose is to analyze what notions of infants parents are met by in direct marketing sent to their home mailbox. The following questions are raised: How are infants visually constructed, and how are they argued to be in need of consumption? What images and notions of infants are posed and sent to parents to make them consume? In other words, how are infants visually constructed as a category and as arguments for encouraging parents to consume and, thereby, as being and becoming part of consumer culture, being and becoming consumers?

\section{Direct marketing}

In Sweden, most families start receiving unsolicited addressed direct marketing concerning child consumption in the mailbox closely after a child is born. This is possible because companies can pay for information (mainly date of birth and address) from the Swedish SPAR register, which contains personal records for everyone living in Sweden. ${ }^{i}$ This is done when companies wish to address a specific group of consumers, for example parents (Statens personadressregister, 2014). For the present study, such unsolicited addressed direct marketing has been collected and analyzed. ${ }^{\text {ii }}$ The collection was performed by three middle-class families living in a medium-sized Swedish town; they were seen as representatives for the consumer target group of people who had recently become parents. The parents saved all direct marketing coming in the mailbox during their first child's first year of life (2008-2012), supplying me with a large marketing material sent by local as well as national and international companies. iii

In one of the families, the mother had blocked her personal record from being handed over from SPAR to companies wishing to send her advertisements. The direct marketing sent to this family was therefore solely addressed to the father, John. Although none of the fathers in the other two families had created a direct advertisement block at SPAR, the mothers in those families, Ulrika and Linn, were the only addressees.

Commodities promoted in the material are mainly related to five themes: children's bodies, ${ }^{\text {iv }}$ children's play, ${ }^{\mathrm{v}}$ knowledge, ${ }^{\mathrm{vi}}$ memorabilia,${ }^{\mathrm{vii}}$ and motherhood..${ }^{\text {vii }}$
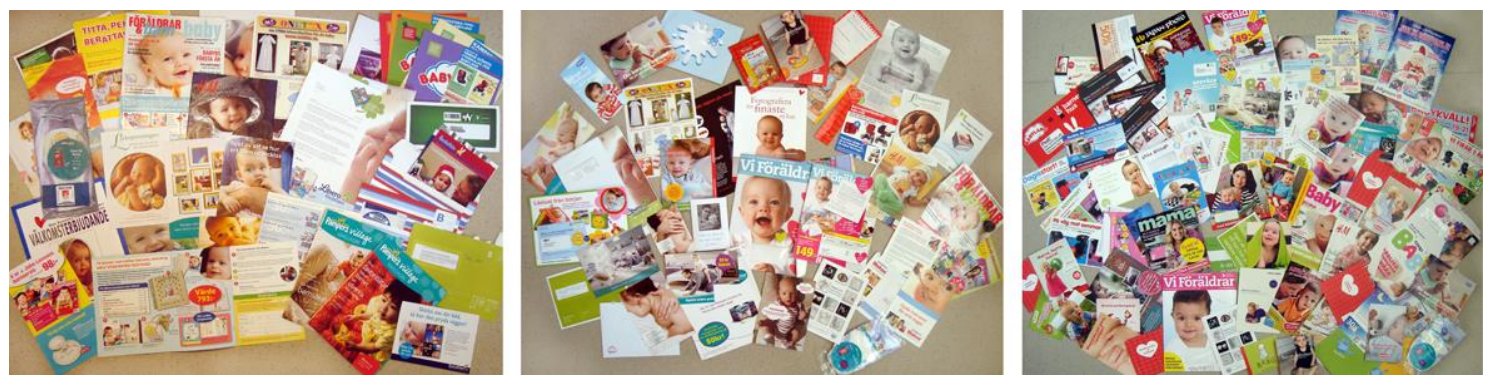

Fig. 1. Direct marketing sent to John during 2008/2009. ${ }^{\text {ix }}$

Fig. 2. Direct marketing sent to Ulrika during 2010/2011. ${ }^{x}$

Fig. 3. Direct marketing sent to Linn during 2011/2012.xi

The collected material is complex, three-dimensional and visual, and consists of postcards, leaflets, brochures, coupons, free samples and special editions of glossy parenting magazines. The magazines both include samples of editorial copy - functioning as an advertisement in itself, encouraging the reader to buy or subscribe to the magazine - and numerous printed adverts. In total, the material consists of 377 different pieces of marketing. Several companies 
are recurrently seen in the collection, thus showing how eager they are for new parents to find their products. However, several other companies are represented in the material with only one advertisement.

When conducting research in the child consumption field, Sparrman and Sandin (2012) stress the importance of situating children in the contexts they appear in. This means putting children in focus, in relation to consumption, and investigating how children take part in or are made part of consumer culture. Many different methods are suitable for this task, as the situatedness calls for specific methods in every single study. The theoretical framing for the present study is an emphasis on the interconnectedness of consumption and visuality (Schroeder, 2002). I situate infants in the everyday visual consumption of direct marketing and scrutinize how they are visually constructed in relation to consumption. A combination of Visual Discourse Analysis (Rose, 2007) and Critical Discourse Analysis (Fairclough, 1992, 1995) are used as theory and method. As "discourse" refers to groups of statements structuring the way something is understood discourse analysis mean scrutinizing how something is being articulated and thereby shaping the world. I have followed the methods call for methodical categorizing and re-categorizing, identifying key themes and clusters of words and images. In this work often-used themes, contradictions and complexity are aimed at being detected. Careful attention has been paid to details in individual images as well as recurring visual patterns in the material collection as a whole. Important is scrutinizing how specific visual articulations are constructed as truthful or natural, and how those particular knowledge proposals affect the social world (Rose, 2007; Fairclough, 1992). Details of the direct marketing guide the investigation, however in conducting and supporting the analysis previous research on the subject functions as a theoretical framework for the study.

Commercial discourses of infants are being activated and negotiated through all parts of the visual communication that the direct marketing consists of and at the intersection of materiality, image and text. The design of the different parts sent, including wrappings and threedimensional objects such as free samples, and the design of the marketed products are thus of great interest. Also of interest is when, in terms of the child's age, certain marketing are sent to the parents, as this says something about when certain products are considered to be important for infants. Central to the analysis are also the 2056 images, or more specifically photographs, of young children, mostly infants, found in the material. ${ }^{\text {xii }}$ Together these aspects of the marketing make up visual-commercial discourses of what infants are - as a category and as consumers.

\section{Images and notions of children}

Sjöberg (2012) has previously discussed the role of fathers in addressed direct marketing. A specific focus on the representation of children in such material is, however, lacking. Previous research on closely related material includes studies on the representation of children in print advertisements published in magazines for parents and women (Cook, 2011; Gram, 2004; Prothero, 2006; Sunderland, 2006). But direct marketing sent to parents is not to be equated with print advertisements in magazines, as direct marketing addresses and targets parents directly at home. It is three dimensional in form and more complex than two-dimensional ads.

Results from previous research show that ads printed for mothers produce and reproduce notions of the ideal childhood, in which growth, care and play are central elements (Gram, 2004). Daniel Thomas Cook (2011a) argues that ads with children show them from the perspective of what mothers want to see, namely the cute, happy and safe child. By this he means that the ads have an inherent female gaze, which he calls "maticularity". Andrea Prothero (2006), who also discusses ads for mothers, shows that fear - of harming the child or being a bad mother - is an often-used strategy in trying to make mothers consume.

The marketing studied here was sent to parents because of their new identity as parents, which put the child at center for this marketing. This, despite the fact that children themselves 
are much too young to be interested in it. The commodities promoted are targeted to parents, to be bought by them, but often to be used by or for the child. This means that infants are actualized in the material, both when young children are visualized in it and when they are not. Thus, images of children are not the only important aspect of the material. Nor is the marketing solely directed at mothers, but at new parents, although it clearly uses a female visual and textual address (Sjöberg 2012). Parents and children are connected through the material because consumption for an infant is part of preparing for the role as a parent and of constructing a parental identity (Thompson and Kehily, 2008; Thomsen and Sørensen 2006). Consumption and the use of commodities are also practices in which parents attribute and construct their infant's identity as, for example, a boy or girl, a cool soccer supporter or princess. All of this places the kind of consumption direct marketing tries to encourage in a borderland between consumption for yourself as a parent and consumption for your child. This means that consumption for infants ascribe infants identities as well as creating them as symbolic extensions of their parents. It is therefore central to understand the ideas and images of what children need and how they are constructed as a category, because notions of a child's characteristics and personality are important to people when they buy things for children (Parsons and Ballantine, 2008). Given that infants, in contrast to most other children, cannot express what they want to be bought for them, consumer decision-making concerning them primarily regard parental ideas about what the infant needs (and wants). The direct marketing can therefore be seen as something that, through constructions of what infants are, need and want, offers parents reasons for consumption. Thus, the direct marketing studied here is seen as something that has the potential to orientate parents in parenthood and consumption as well as to function as a source for parents to make meaning in relation to infants. It can be seen as a form of consumer socialization into parenthood (Sjöberg, 2012).

Ideas and notions regarding children are closely connected to images of children, and for this reason previous research on representations of children in advertisements and other visual imagery is important to the present study. Prominent in this field is art historian Anne Higonnet (1998), who shows that romantic images of passive children dominate the visual culture in the West. She argues that, despite societal changes, new techniques for image production and many different reasons for visualizing children, the romantic, cute and naive child is still the most reproduced. Although her empirical material is not mainly commercial, she does remark that the romantic child is particularly common in the commercial imagery. Historian Gary Cross (2004a), writing about advertisements published in the US during the 2000th century, agrees. He argues that children are often portrayed in advertisements in a romantic fashion, with an expression on their faces he calls "wondrous innocence". The typical scenery for "wondrous innocence" is seen in images showing children in front of a Christmas tree surrounded by unwrapped presents.

Cross also argues that a cool child image has started to compete with the cute and innocent child. He asserts that the elements of youth culture, disgust, fear and toughness are increasingly used in relation to children, in for example toys (Cross 2004b). But he does not analyze pictures of children. Chris Boulton (2007) who does, discusses the visualization of cool children in advertisements, arguing that 'cool' is made up of cocky and serious expressions and that the pictures bears a close resemblance to visualizations of adults. This is reminiscent of Higonnet's (1998) analysis of the increasingly common way of depicting children in art, as disturbingly knowing of the adult world. She argues that this is a more complex way of interpreting childhood that no longer presents children as objects for visual pleasure. But neither the cool nor the knowing child image are discussed, or seem to be used, when it comes to the youngest children.

On the other hand, Patricia Holland (2004), who discusses popular cultural images of children, devotes a whole book chapter to infants. She comes to the conclusion that the youngest are often portrayed as visually attractive little angels or cherubs. This ties in to Higonnet's (1998) argument that commercial images most often depict children in a romantic 
and nostalgic manner, and that a common way of doing this is as angels, cherubs or fairies. The connection between children and angels is furthermore discussed by Gill Valentine (1996). She argues that the hegemonic understanding of children today is as angel-like and innocents. At the same time, however, there is a widespread understanding of children, particularly youths, as dangerous and uncontrollable devils. Chandra Mukerji (1997) also reasons about this duality, arguing that young children are interpreted as immensely valuable and in need of being treated in an understanding way, on the one hand, and are seen as disruptive little monsters, on the other.

Summarizing previous research on child images, it is possible to pin-point two different visual discourses; the positively innocent, angel-like child, and the cool, disturbingly adult-like child. However, historian Tora Korsvold (2012), who has analyzed ads from the Norwegian clothing manufacturer Helly Hansen, finds another manner of representing children. She shows that, from the 1980s onwards, children are being represented as positively active, strong, curious and competent individuals. This suggests the passive romantic child image as well as the image of the cool and frightening child is being challenged or at least that images of children need to be seen as more complex than previously suggested. What is problematic for the present paper, however, is that Korsvold, like Cross and Boulton, fails to discuss whether infants are seen among the children reproduced and interpreted in the study.

\section{Analysis}

I will now discuss the three dominant visual-commercial discourses of infants in the studied direct marketing material. I call them "the angel", "the adventurer" and "the transformer". In line with Higonnet's (1998) and Holland's (2004) analysis of art and popular images, infants in the first discursive formation visually resemble angels and cherubs. However it is not only the image of the infant itself that is important in constructing the visual-commercial angel. The visual presentation and design of the commercial goods are also vital, as well as the marketing design and texts. In my analysis, I show how these aspects of the marketing interact in constructing "the angel" as well as "the adventurer" and "the transformer".

\section{The Angel- emotions and solemnity}

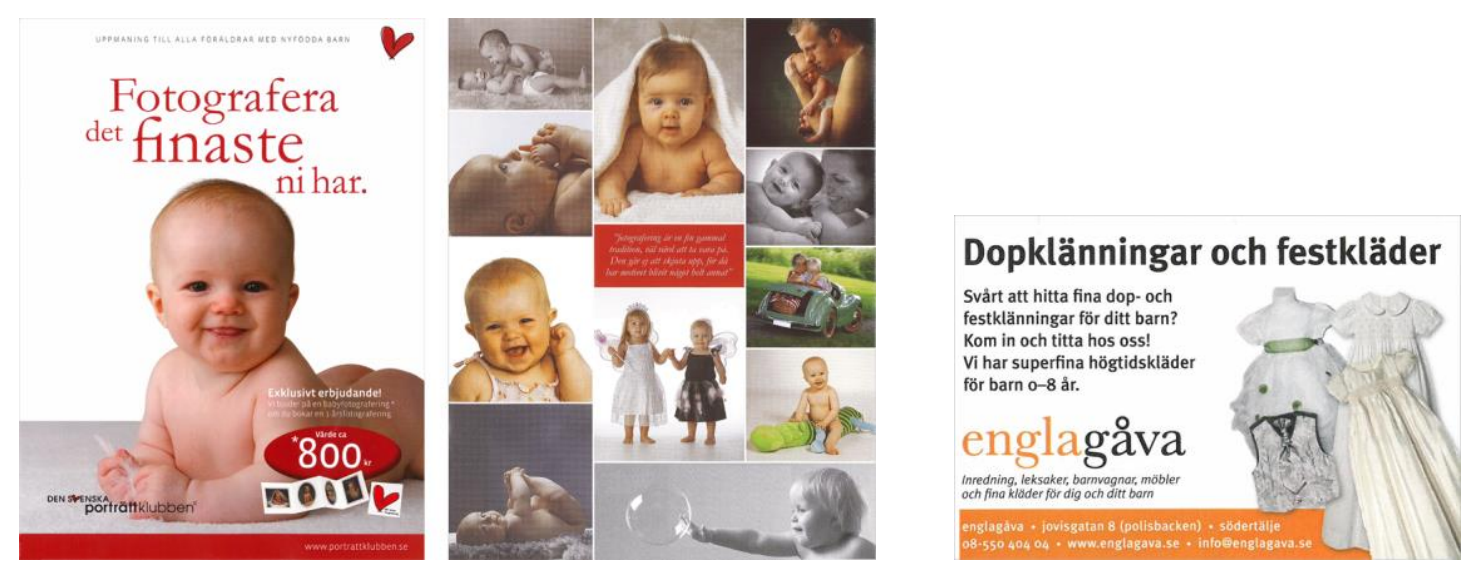

Fig. 4. Front page and inner page from a leaflet sent by The Swedish portrait club, which is an association of professional portrait photographers. Sent to Ulrika.

Fig. 5. Advertisement for christening robes and festive clothes from Englagåva. In Vi Föräldrar Baby, p.46 (The name Englagåva is a misspelling of "angel gift" in English.) Sent to Linn. 

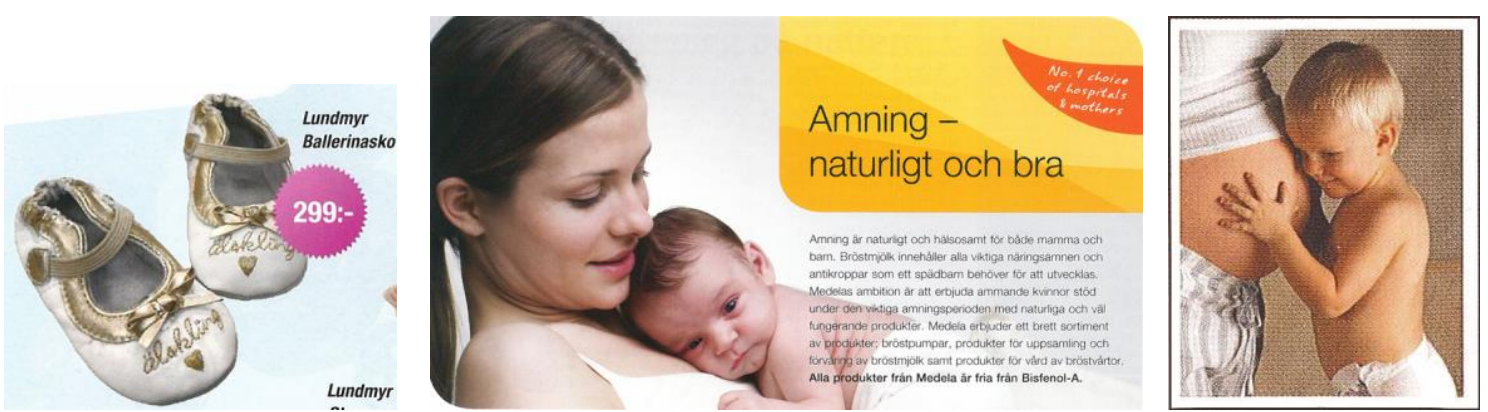

Fig. 6. White and gold baby shoes with hearts and the text "darling". Marketed in a product catalogue from Jollyroom.se. Sent to Linn.

Fig. 7. Advertisement for breastfeeding equipment, published by Meddela in Vi föräldrar Baby (2010) p. 44. Sent to Ulrika.

Fig. 8. Part of leaflet sent by The Swedish portrait club. Sent to John.

Characteristic of the visuality of the angel category is a light, airy or fluffy environment, including such things as soft fabrics, white clouds, rounded shapes or the safe body of a parent. The infants shown are often very young or newborns, but not exclusively. We can, for example, see older children provided with wings resembling fairies in the middle of the inner page of a leaflet sent by The Swedish portrait club in Figure 4. Common to all bodily representations of children as angels are the constructions of them as beautiful and passive. They are either introverted or absorbed in themselves, often sleeping or gazing distantly, or facing the camera acknowledging the viewer's admiring gaze. They are often dressed in white or pastel clothes or are undressed, showing a lot of chubby flesh, letting the viewer come close and almost feel the softness of their skin. Professional photographers, but also marketed clothes, offer parents opportunities to visually construct their own infant as an angel. In Figure 5 and 6, we see the marketing of white cute clothes with a nostalgic touch, showing how this ideal is connected to festivity, solemnity and emotions.

Figure 7 represents another aspect of the angel, namely children as both natural and magical. The ad promotes breastfeeding equipment, with a headline highlighting that breastfeeding is good and natural. Visually, this advertisement relates to the many similar images of loving mothers holding or breastfeeding their newborns and images of pregnant bellies in the material, for example Image 8 . The mother and child are visualized as being in a natural symbiotic relationship and become a symbol for the beginning of life, reminding of how miraculous life is.
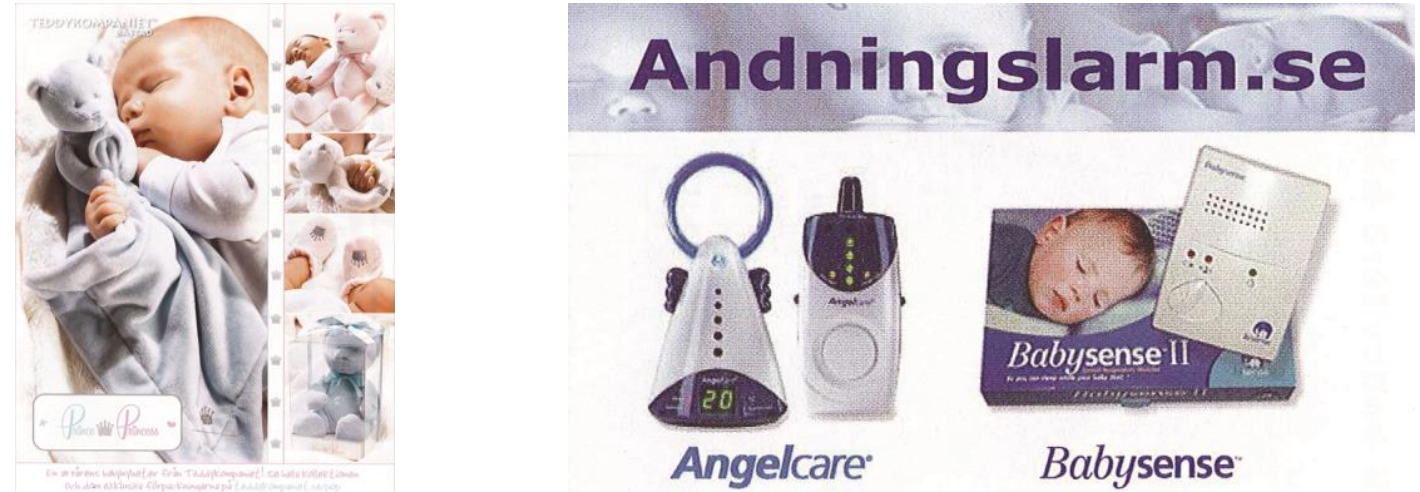

Fig. 9. Advertisement for soft animals and baby slippers, published by Teddykompaniet in Föräldrar \& Barn Baby (2011) no. 1, p.17. Sent to Linn.

Fig. 10. Part of advertisement for baby breathing alarms and monitors, published by Andningslarm.se, in Föräldrar \& barn, baby (2008) p. 46. Sent to John. 

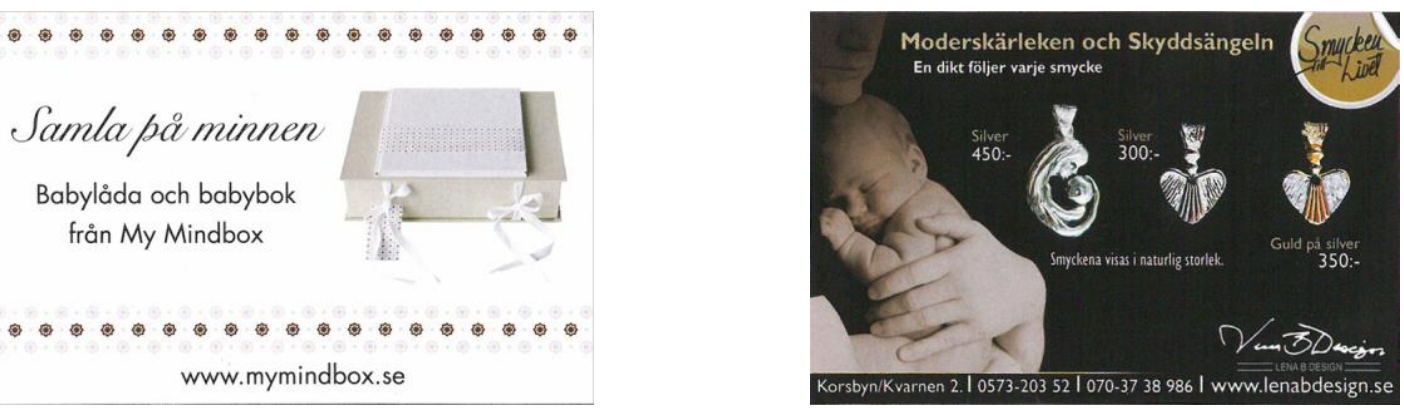

Fig. 11. Advertisement for a baby memory box. Published by Mymindbox.se in Baby, Föräldrar \& barn, p. 47. Sent to Linn.

Fig. 12. Advertisement for silver charms called "mother's love" and "guardian angel". Published by Lena B. Design in Föräldrar \& Barn; Allt det bästa för din baby (2010) no. 1-10, p. 46. Sent to Ulrika.

Children as angels appear as being connected to the magical beginning of life, but they are at the same time often visualized as very still and in need of peace and quiet (Fig. 9), often making them resemble dead children (cf. Weaver-Hightower, 2012; Jensen, 1994). The end of life is furthermore actualized by the many advertisements marketing baby breathing alarms, such as in Figure 10. In that advertisement, we can see a transmitter shaped like an angel and designed to be placed next to the sleeping child, to watch over it like a guardian angel, preventing the child from becoming a "real" angel in heaven. This shows that the angel category encompasses both life and death, actualizing existential questions and fears.

Loss, nostalgia and love are furthermore actualized in the design of the baby memory box in Figure 11. The box, which resembles a little white coffin, is intended for small mementos collected during infancy, saving lost times and the preciousness of the period when the child is very young. In Figure 12, silver charms called "mother's love" and "guardian angel" are sold together with a poem. Also this advertisement touches on values of solemnity and love as well as talking about the need for the child to have a guardian angel. Together advertisements like these construct children as invaluable objects of parents' love, a love that is to be manifested through products that can be displayed and kept.
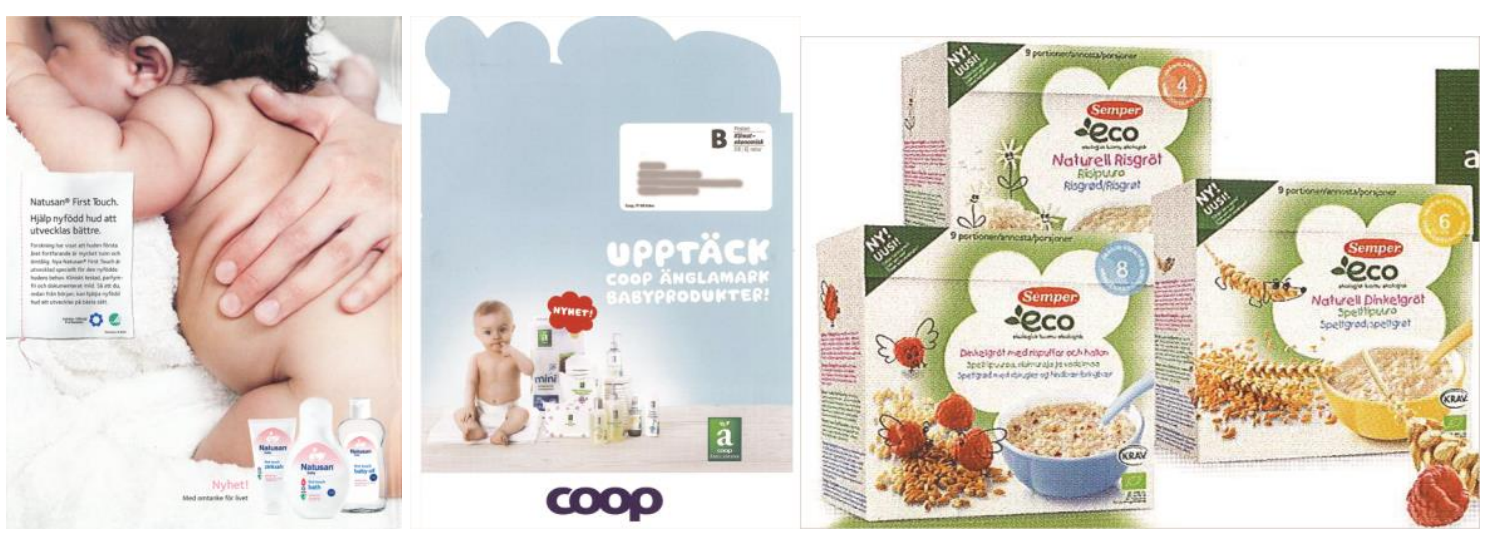

Fig. 13. Advertisement for baby skin products from Natusan, Published in Allt det bästa för din baby Föräldrar \& barn, no. 1-10, p. 2, Föräldrar \& Barn Allt det bästa för din baby (2010) p. 2 (sent to Ulrika), Föräldrar \& barn, Baby (2011) no. 1, p. 2, Vi Föräldrar Baby (2011) p. 2 (sent to Linn).

Fig. 14. Front page of leaflets for Coops ecologic series Änglamark (angel ground in English). Sent to Linn.

Fig. 15. Ecological porridge. Part of folder from Semper. Sent to Linn. 
Another way to manifest love is through care, and in relation to the angel category care is suggested to be dependent upon high quality products with natural and ecological ingredients (Fig. 13, 14, 15). Rounded forms, pale colors and white clouds seem to promise that these products are as pure and innocent as the precious child they are intended for. Visually, the companies ensure that the products treat children with the same softness and purity as they treat the environment, and vice versa.

The angel is made as a pure and nostalgic being, both human and amazingly magic. These aerial angels are constructed as the most precious beings, worthy of worship and worthy of the very best and well-considered consumption. Despite the passiveness connected to the category, this makes the angel infant an actor working as a lobbyist for consumption. The etheric delightfulness is to be preserved for the future in numerous consumer goods, to be remembered and worshipped through memorabilia and symbolic goods such as jewelry and bric-a-brac. The angel seems to demand consumption equal to its lovely and beloved qualities and commodities of particularly high quality, as well as commodities that tend to the angel's need for a kind of calm and soft nurturing. In combination with this, parents are constructed as worshipping and loving parents that need to cuddle and protect the infant, and that is to be done with consumer products.

Particularly common products marketed in relation to this category are professional photography (Fig. 4), baby breathing alarms (Fig. 9), products related to pregnancy and breastfeeding (Fig. 7) and memorabilia and symbolic jewelries (Fig. 10, 11). The "angel" is also seen in marketing for a range of other products where values such as tranquility (Fig. 8), loving emotions (Fig. 6), care and purity (Fig. 12), ecological concern (Fig. 13, Fig. 14) and high quality are highlighted.

\section{The Adventurer-activity and joy}

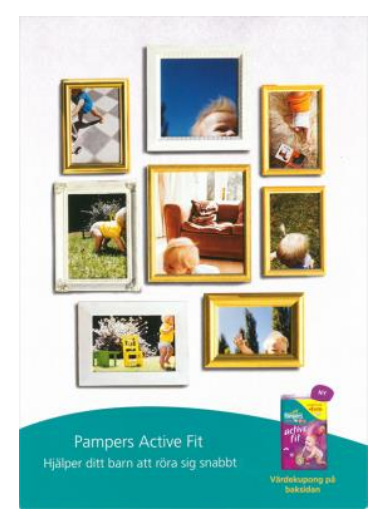

Fig. 16. Front page of postcard for Pampers Active fit diapers. Sent to John.
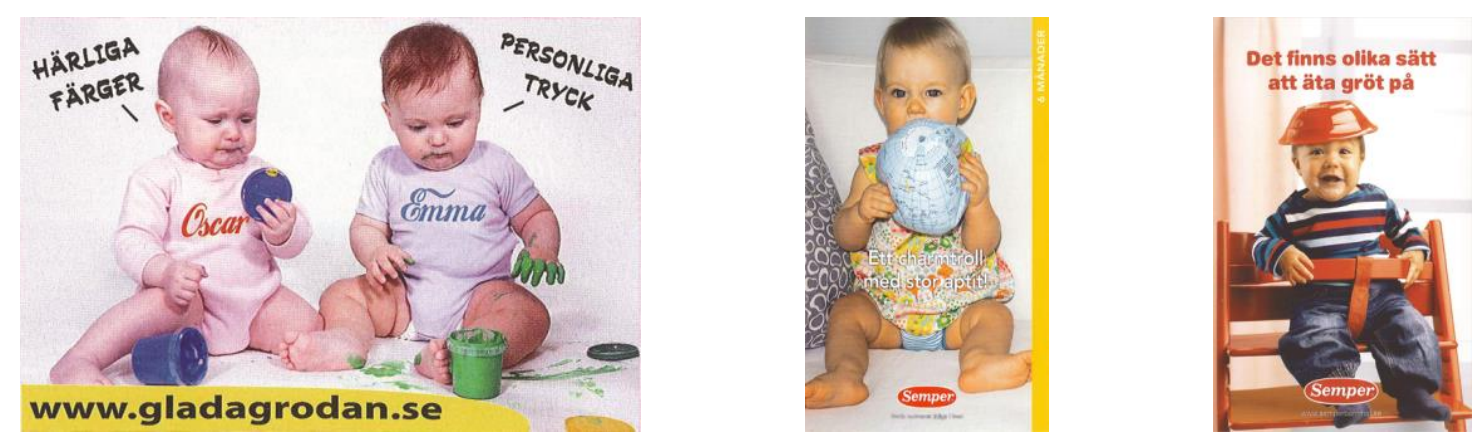

Fig. 17. Advertisement marketing clothes from gladagrodan.se, Föräldrar \& Barn Baby (2011) no. 1, p. 
44. Sent to Linn.

Fig. 18. Part of information book about children's food produced by Semper. The heading says; " $A$ charmer with great appetite". Sent to Ulrika och Linn.

Fig. 19. Front page of folder from baby food manufacturer Semper. The heading says; "There are different ways to eat porridge”. Sent to Linn.

The second category, the "adventurer", is both visually and as a consumer object distinctly different from the angel. Instead of beauty and stillness, and white and pale colors, here we find lively infants surrounded by bright colors. This is a presentation of infants as curious, active and very physical, and as having their own inner driving force. In Figure 16, the children seen are so on the move that the camera cannot even seem to capture them in the frame.

Children as adventurers are constructed as colorful and imaginative individuals, often shown exploring their surroundings and the world. The adventurer is described as hungry for experiences, play and adventures - as awake, happy and ready for new discoveries. The infants in Figure 17 are exploring the taste and touch of paint, orienting themselves to the world around them. In Figure 18, an infant is shown taking a big bite at an inflatable ball in the shape of the earth. The infant is presented as "A charmer with a great appetite". This text can be related both to the baby food the company is promoting and to an appetite symbolically directed toward the outside world. In any case, the infant is constructed as someone who is always ready for experiences. In Figure 19, we see a mischievous infant with porridge smeared on its face and a red bowl placed on top of its head. The text, "There are different ways to eat porridge", shows a humorous acceptance of children's ways of doing things, signaling that it is and should be joyful to eat Semper porridge, regardless of whether it is done properly or not.
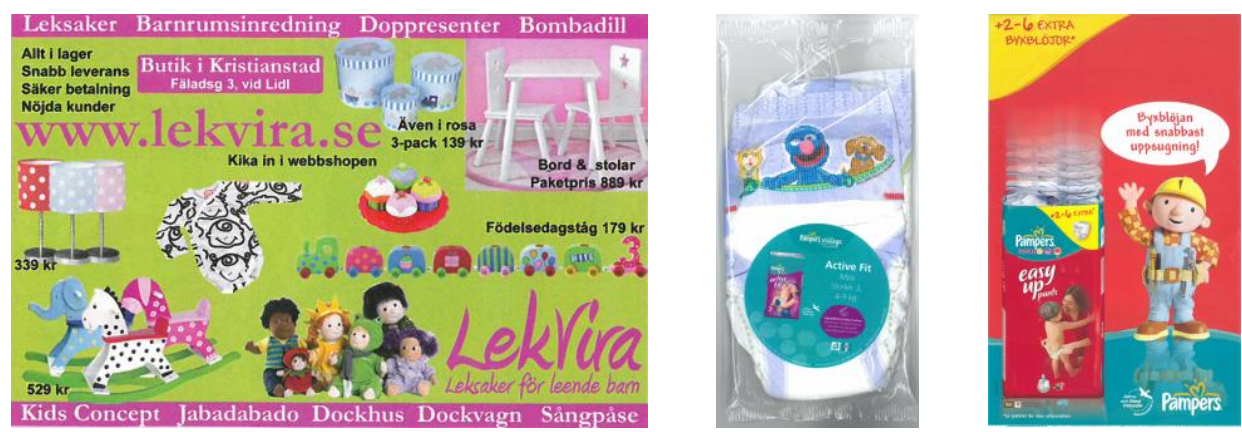

Fig. 20. Advertisement for toys from Lekvira, with headline saying "toys for smiling children". Published in Föräldrar \& Barn Baby (2011) no. 1, p. 47. Sent to Linn.

Fig. 21. Diaper with colorful figures from Sesame Street sent as a sample from Pampers to Ulrika.

Fig. 22. Leaflet with Bob the Builder, sent together with a diaper from Pampers to John.

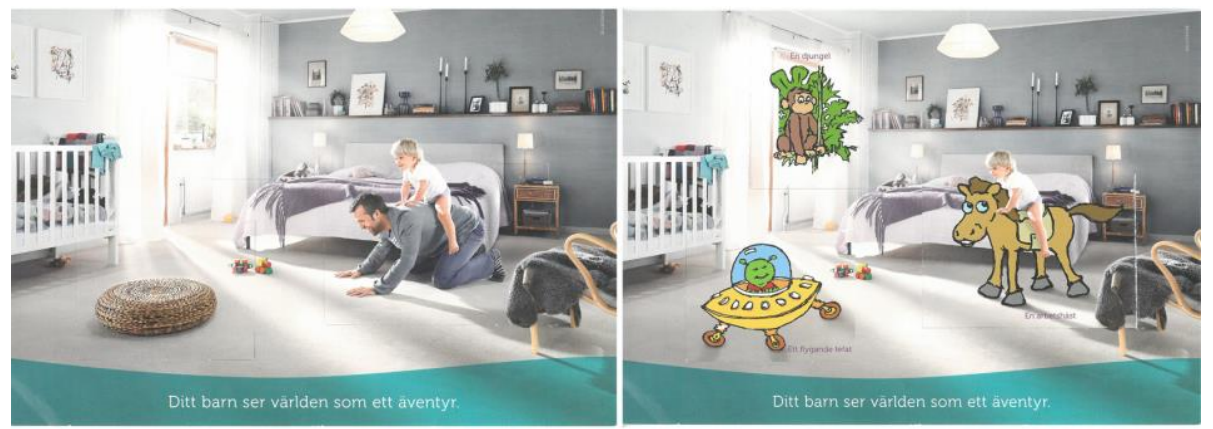

Fig. 23. Leaflet marketing diapers from Pampers. The left image shows the original image. The right 
image shows what it looks like when three paper doors are taken away, suggesting to show in what an imaginative way children see the world around them. The text says "Your child sees the world as an adventure”. Sent to Ulrika.

Infants in the adventure category are often seen to climb, eat, swim, touch different things, mess about, move around and make noise. In this way, infants are presented in stark contrast to the angel and have other commodities attached to them. As we can see in Figure 20, bright colors are used both in the design of the ad and on the toys being marketed. The diaper shown in Figure 21 is decorated with colorful figures from Sesame Street, and in the leaflet sent with another sample diaper Bob the Builder is seen waving at us (Fig. 22). The imaginative and colorful visuality with patterns and funny figures connects children to aspects of imagination and entertainment.

"Your child sees the world as an adventure" is what a leaflet from Pampers informs us of (Fig. 23). The leaflet has small doors that can be opened, showing two different "worlds". One is the rational world that children share with adults and the other shows the adventurous and imaginative world that Pampers suggest children experience. All together a logic of infants as innovative, playful, colorful and imaginative appears, and of needs to be met by equally innovative, playful, colorful and imaginative products. This notion of children calls for the consumption of many different products, where design and function seem to prevent dreariness and enhance the joy of life. Thus, this visual-commercial discourse calls for commodities that encourage this adventurous infant to explore. Accordingly, parenthood is constructed as something that has to be indulgent and permissive, allowing the infant to enjoy exciting things, new flavors and stimulating experiences in its own way.
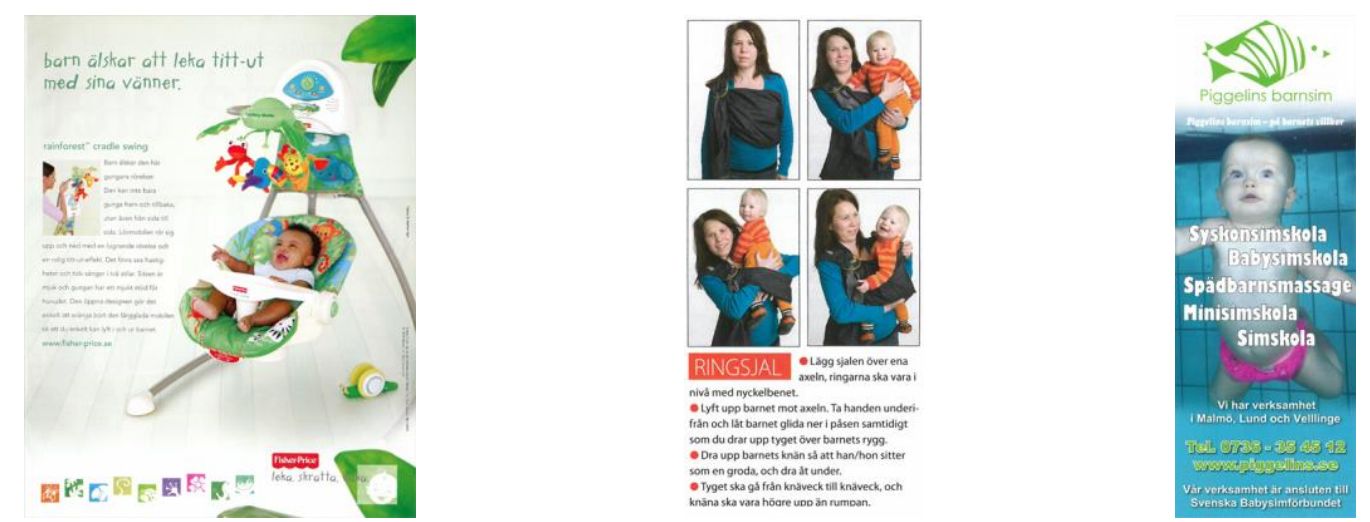

Fig. 24. Advertisement for entertaining cradle swing from Fisher-Price. The heading says "children love to play peekaboo with their friends”. Published in Föräldrar och barn Baby (2008), no. 1, p. 13. Sent to John.

Fig. 25. Part of parenting magazine showing how to use shawls to carry babies. Föräldrar \& Barn Allt det bästa för din baby. (2010) no. 1-10, p. 36. Sent to Ulrika.

Fig. 26. Advertisement for Piggelins swimming classes for children. Published in Föräldrar \& Barn Baby (2011) no. 1, p. 19. Föräldrar \& Barn Allt det bästa för din baby. (2010) no. 1-10, p. 24. Sent to Linn and Ulrika. 

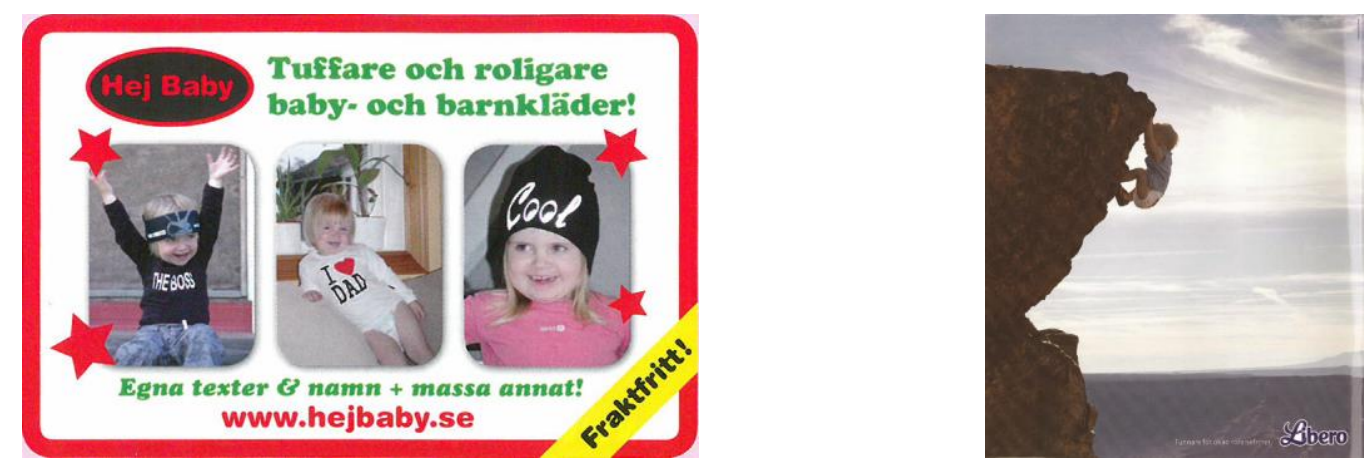

Fig. 27. Advertisement for baby and children's clothes from hejbaby.se. Published in Föräldrar \& Barn Baby (2011) no. 1, p. 45. Sent to Linn.

Fig. 28. Advertisement for Libero diapers. Published in Föräldrar \& Barn Baby (2011) no. 1, p. 52. Sent to Linn.

This active infant also needs well-made products to match its lust to explore, for example strong clothes for wild play that hold up for many washes and diapers that allow freedom of movement (Fig. 28). All this relates to Korsvold's (2012) study, where individuality, activity, playfulness, joy, curiousness and rich colors are seen in how children are represented in advertisements for what is said to be comfortable and heavy-duty clothes. Thus, here the individual child is constructed as more of a happy wild child than as a cool adult-like and serious person, as proposed by Boulton (2007). Cool is nevertheless also represented in the text (Fig. 27) and on some products printed with, for example, skulls. But cool does not construct children as little devils or monsters, rather this appears as a humorous play with identity and the meaning of childhood (Fig. 27, 28).
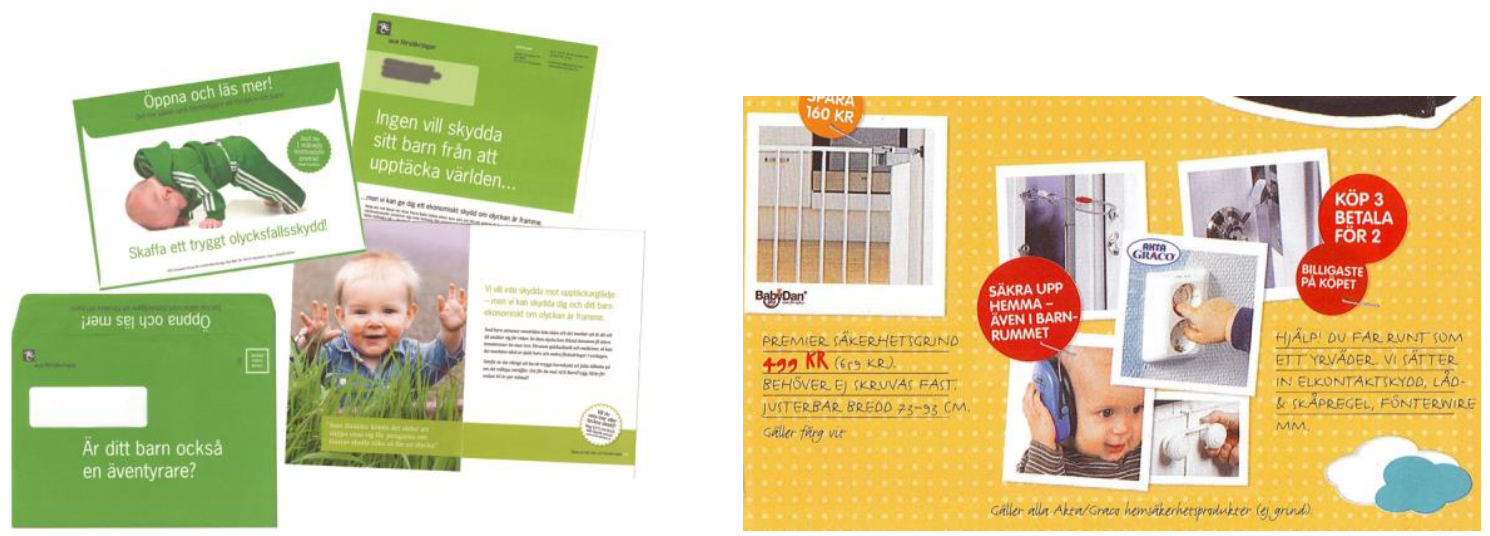

Fig. 29. Mailing from Ace insurance company, marketing child insurances for "adventurers". Sent to Linn.

Fig. 30. Part of brochure marketing child safety products. Sent from Babyland to John.

Another aspect of the infant as an adventurer is that its lively and curious character risk putting it into danger. Therefore child insurances, safety products and carseats to prevent accidents and injuries to the child are gratefully marketed in relation to this category. We see this in Figure 29, where insurances for children, explicitly called adventurers, are marketed with an image of an infant in a bright green tracksuit making moves reminiscent of push-ups. In Figure 30, a chubby finger is seen fiddling with an electric socket next to the text "Help! You get around like a madcap. We install electric socket covers, locks for cupboards and drawers, wires for the windows etc". 
Other examples of products marketed in relation to the adventurer are baby food (Fig. 18, 19), clothes (Fig. 17, 20), entertaining fun-looking products (Fig. 20, 21, 24) and baby swimming classes (Fig. 26). The "adventurer" is also seen in marketing for a range of other products when the marketing, in different ways, enhances or visualizes values of colorfulness and playfulness (Fig. 25, 26), when the physically active and curious child is seen (Fig. 18, 25) when children are suggested as having a vivid imagination (Fig. 23) and when they are constructed as social and extrovert together with other people, such as friends and family (Fig. $23,24,25)$.

\section{The Transformer-development and change}

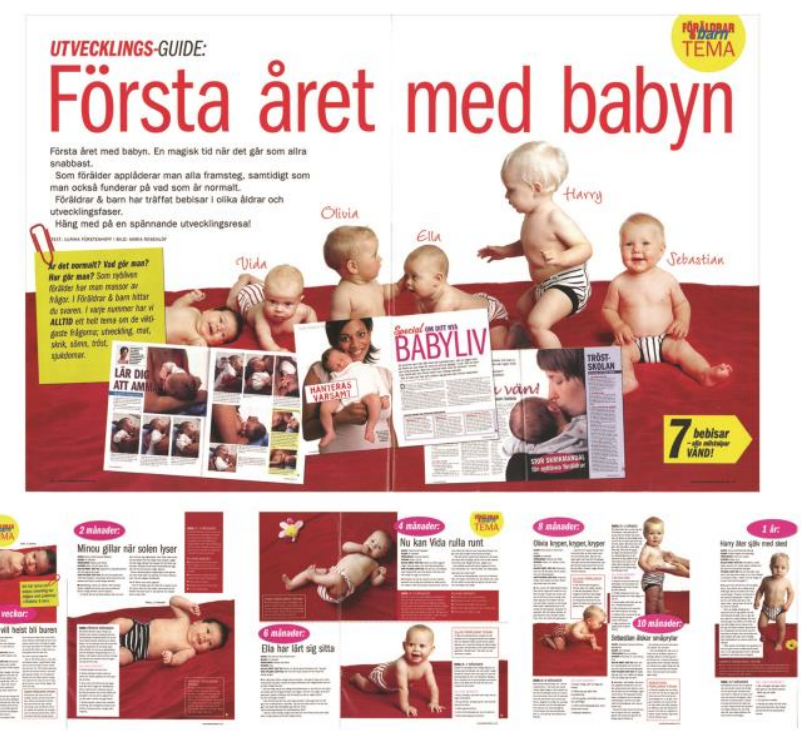

Fig. 31. "Developmental guide: the first year with the baby", Föräldrar \& barn baby (2008) no. 1, p. 1422. Sent to John.

The last category, "the transformer", is the most complex, and the less visual of the three visualcommercial discourses. The two central themes in it is the infant as a becoming (Lee 2001, 5) and the child's status as a transformer of its parents' lives. These aspects are most often expressed through text, but one way the "transformer" comes into being visually is in images of children representing different phases of development. In Figure 31, we see the visualization of the transformer in one of the parental magazines. Infants of different ages form a "Developmental guide" to the first year. Each child is made to represent a developmental phase, next to text describing what knowledge the child will have mastered at that point. Every fact presented constructs a claim of truth that, when related to each other, creates a movement in which infants naturally change along a path toward more knowledge, better understanding and increased physical competence. This is the infant as a natural becoming. 
Under det första året läggs den viktiga grunden för barnets utveckling!

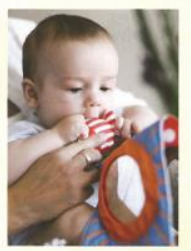

0-6 mảnader

Typiskt fôr barnets utveckling under den här perioden: Rygg- och nackmuskulatur stârks, synen vidareutvecklas
och barnet börjar utforska med händerna och lyssnar aktivi Bra samspelsaktiviteter: Fá bra ógonkontakkt med barnet, prata med barnet och
sjung for det Lätt beróring, vaggande, barande och lek

Frán Goboken i denna perioden:

Frân Goboken i denna perioden:
Till babyn far du enkla bocker (gäma mjuka). lekssaker och

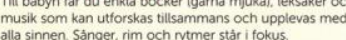

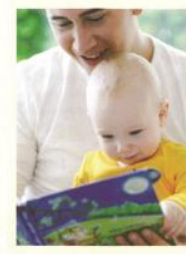

6-12 mảnader Typiskt för barnets utveckling under den här periodern
Barnet bir mer intresserat av sin omgivning, det kan farnet bir mer intresserat av sin omgivning, det kan
flera nya lijud och kommer snart att sága sina forsta ord Bra samspelsaktiviteter: Situationer där barmet skrattar, pekar, härmar
kommunicerar aktivt med liud och gester. Fran Goboken i denna perioder: Nu fâr du enkla och stadiga bocker med väkảnda óremál, situationer roch jjur. Böckerna har ofta

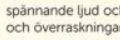

Fig. 32. Part of leaflet marketing age adjusted books from Goboken. Sent to Linn.

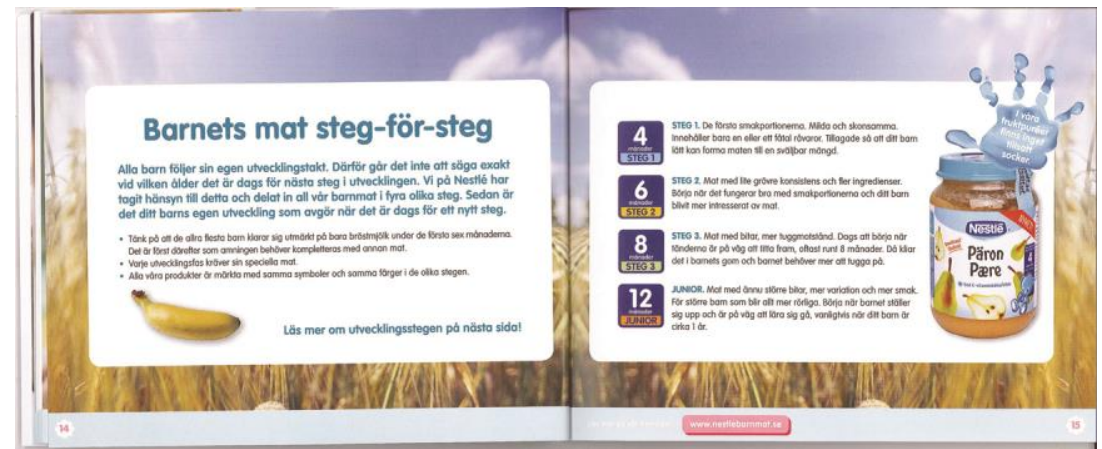

Fig. 33. "Children's food step by step”. Double page in brochure about children's food published by Nestlé. Sent to Linn.

Much of the marketing sent to the families is matched to the age of the child in the addressed family. Marketing for baby food for 4-month-olds turns up when the child is four months, and coupons for cheaper diapers adapted to 6-month-olds turn up when the child is six months. This shows that direct marketing practices build upon the idea that children in the same age range have the same requirements, problems and consumption needs.

Products adapted to age and developmental phases are also part of constructing the transformer category. In Figure 32, books from Goboken adapted to 0- to 6-month-olds and 6to 12-month-olds are marketed. The children in each category are described as having specific skills and interests, and the books for them are argued to be matched to these stages. In a spread from a brochure about children's food, published by Nestlé, a similar description of infants as divided into age groups is seen (Fig. 33). In this case, there are four steps. Step 1 is baby food for 4-month-olds marked light blue (as is also seen on the lid and label on the can with pear purée), Step 2 is for 6-month-olds, marked yellow, Step 3 is for 8-month-olds, marked light green, and Step 4, marked orange, is for 12-month-olds. Although Goboken and Nestlé do not divide infants into the same age groups, both companies regard infants in a similar way. The core is an understanding of children as being in change and that this should be matched with age-adapted products. Infants and commodities are hence constructed simultaneously; the products are adapted to infants, and the image of infants is adapted to the products. 


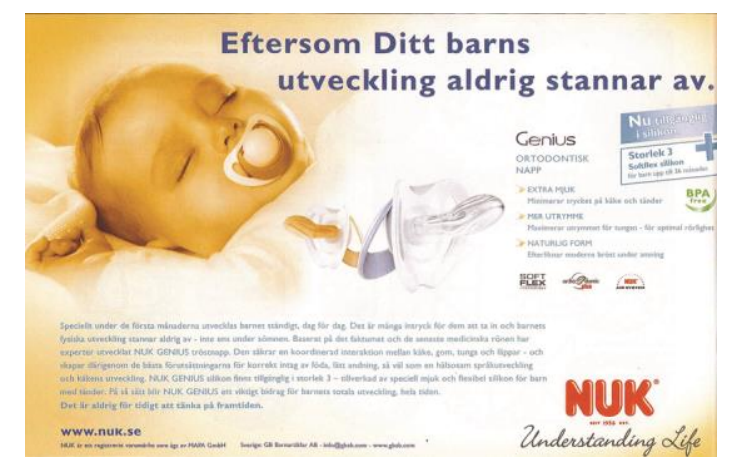

Fig. 34. Advertisement for NUK pacifiers. Heading says: "Since your child's development never stays still”. Published in Föräldrar \& Barn Baby (2011) no. 1, p. 42. Sent to Linn.

Furthermore, products marketed as having qualities that enhance the child's development construct infants as transformers. This is done, for example, in an advertisement for NUK pacifiers (Figure 34). Visually this infant is similar to an angel, but the text constructs it as a transformer as the pacifiers are argued to be medically adjusted to the child's development. They are argued to "secure a coordinated interaction between jaw, tongue and lips to give the best conditions for correct food intake, easy breathing and healthy language development and development of the jaw". This shows that the pacifiers are marketed as an important contribution to the child's total development. The text is completed with the statement that "it is never too early to think about the future". Here, naturally occurring development is not natural, but needs commodities if it is to proceed properly.

The repeated focus on development constructs notions of normality, which simultaneously stigmatize children who are different (James, Jenks and Prout, 1998). This can easily evoke fears for the abnormal. A notion of children's development as being both naturally occurring and as requiring different forms of input creates an ambivalence in the interpretation of what children are (Castaneda, 2003). This combination of fear and ambivalence in relation to naturally occurring development is taken up by marketers to their great advantage, as any problem can be matched with a problem-solving product (Pugh, 2005). The "transformer" hence causes parents to continuously evaluate the child's development and to consume the right products, both to adapt to and to improve the development at the right time. This means that parents constantly need to consume specially adapted products. It articulates a demand on them to be active, engaged and highly consuming parents that need to be very attentive to the child's developmental changes and needs. In the long run, this means that children, at any age, to be properly cared for, are always in need of ever new commodities and consumption.
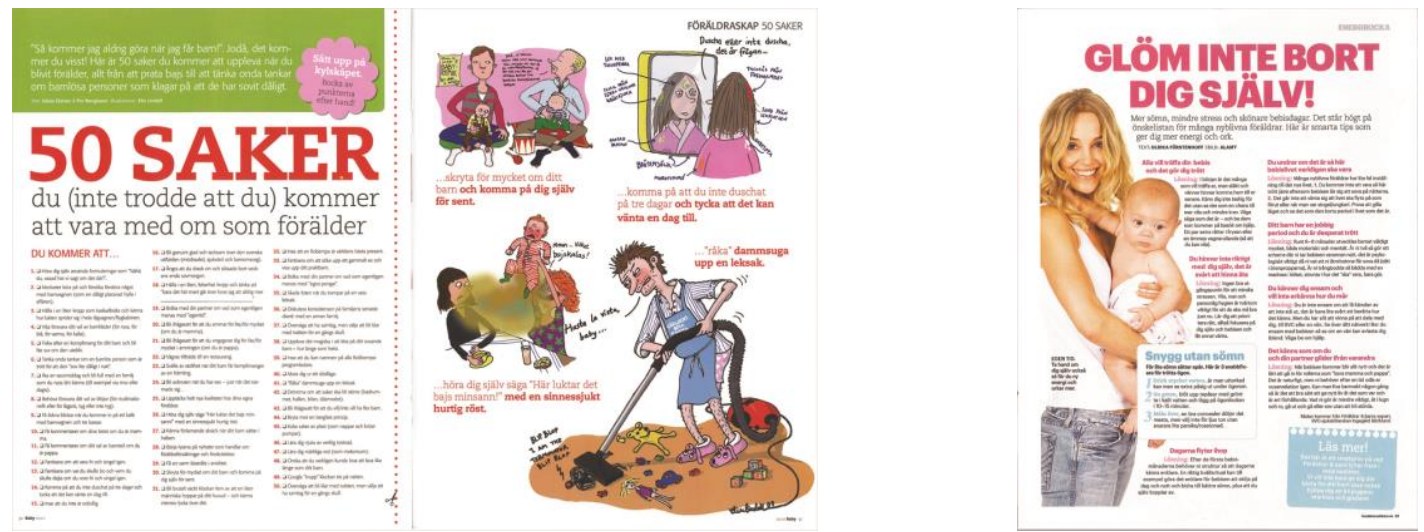

Fig. 35. "50 things you (didn't think you would) experience as a parent", Vi Föräldrar baby, (2010) p. 
30-31 Sent to Ulrika.

Fig. 36. "Don't forget yourself!", Föräldrar \& Barn Baby (2011) no. 1, p. 23. Sent to Linn.

Simply by being born, the transformer changes the life and existence of its parents. This is something that is often repeated in the parental magazines sent to parents as marketing and requests for subscription. In them parents are said to find themselves in a state of chaos when their newborn arrives, later on finding themselves in a new order. The magazines are advertising themselves as being the guide to finding that new order and to helping parents understand what they are experiencing. Figure 35 and 36 are examples of what this guiding looks like. The spread in Figure 35 lists 50 things parents experience as parents but that they could not have imagined beforehand. One of the images, for example, shows a tired and dirty looking mother in front of a mirror, above the text "You will) realize that you haven't taken a shower in three days and think it can wait another day". Figure 36 shows a very happy and healthy looking mother standing next to the heading "Don't forget yourself!". The article argues that forgetting about oneself happens easily when one has a small child. But it is something that does not need to happen. It is said to be important that parents take time for themselves, without the child, which is paradoxical, as the overall message is that the child is the most important thing in a parent's life. Yet arguing for boundaries to keep the infant from taking over one's life constructs children as a transformative power that is also a potential threat to some aspects of adult life.

In relation to the child's physical and cognitive development, the transformation of parents' lives will continue constantly. This makes the child into an actor who partakes in creating parenthood and family life. At the same time, parenthood is constructed as a series of everchanging challenges. In the direct marketing, this challenge is used as a reason for consumption that can facilitate the administration of family life, but also for consumption that improves parents' knowledge of developmental stages by books and magazines about the challenges of being a parent. The core of the discourse of infants as transformers is thereby the child as a project (Halldén, 2007) as well as a life project for consumption.

Examples of products marketed in relation to this category are products argued to be especially designed for the child's age and stage of development (Fig. 32, 33) or that are claimed to enhance development of some kind (Fig. 34). The discourse of the child as a transformer is also seen when children are visualized as developing according to distinct stages (Fig. 31) or as turning parents' lives upside down, giving them new and challenging directions (Fig. 35, 36).

\section{Ideals and concerns demanding consumption}

"The angel", "the adventurer" and "the transformer" are discourses that function as strong claims of truth, covering many different aspects of what and how infants are. Together these "truths" reach into the everyday life of new parents, requesting them to relate to it while considering how to best care for their own infant while navigating their own new identity as a parent. These three visual-commercial discourses of infants therefore play a role in parents' constructions of meaning and, hence, have the potential to influence how parents interpret their role as a consuming parent and how they relate to their infant.

The marketing uses a female address that asks the addressee to look at it from a mother's perspective (Sjöberg, 2012; Sunderland, 2006). This is reminiscent of Cook's (2011) discussion of ads showing children and which he claim contains a female gaze: "maticularity". His concept captures aspects of children that mothers want to see, more specifically the cute, happy and safe child. My analysis shows that the positive aspects connected to joy, happiness and safety are alternated with aspects of risk and threats. The embedded ideals are contested and strengthened by narratives that draw upon parent's fear of child death, accidents, abnormalities and deviant development. In contrast to Prothero's (2006) study, where she shows that fear is a well-used strategy to address mothers in advertising, these threats are seldom explicitly articulated. It is 
rather a threat embedded in the discourses of what infants are.

The delightful "angel" balances visually between existence and non-existence, flows between fantasy, the past and present, and thereby elicit nostalgia, fears of loss and existential questions about life's beginning and end. The passive, silent and still angel also visually resembles images of dead children. The joyful "adventurer" is a strong individual, but its curiousness might lead to accidents and incalculable consequences, and thus requires parental readiness for the unforeseen and risky in everyday life. Adventurousness thereby goes hand in hand with physical and economic damage that must be prevented by consumption. "The transformer", who is an exciting promise for the future, must also be guarded and nurtured to accelerate "normal" development. A threat of developmental delay is constantly present, as well as the risk that parents themselves will disrupt the ideal and expected development if they are not engaged enough, as attentive parents and as consumers.

That these threats are built into the discourses of what infants are means that the overall message is that infants, no matter how they are interpreted, always need consumer products to avoid harm. Moreover consumption is required now - before it is too late. The angel must be photographed and preserved through memorabilia before it loses its angel-like character, and it requires products that secure its present need for stillness and purity. Moreover it requires products that ensure it does not die in its sleep. The adventurer needs consumption in the moment or else its curiousness will not be prevented or enhanced, but also because the infant's inner drives risk putting it in danger. Consumption of exciting products, but also security products such as insurances, carseats and devices to install at home for securing electric sockets, windows and stairs need to be purchased before any accidents happen. The transformer infant and its parents are in need of massive consumption and of knowledge related to development and change so that the infant will truly develop in an optimal way, starting from day one. But also so that the parents can cope with parenthood and its constant transformation, connected to the child's developmental phases and growth.

As the marketing is mainly addressed to and visually addresses women, these discourses are primarily presented to women to reflect and decide on. This adds to an already sensitive and demanding situation, where both the identity as a parent and the role as consumer in the child consumption area are new to mothers, something Davies et al. $(2010 \mathrm{a}, \mathrm{b})$ have shown to be very frustrating.

\section{Conclusion}

I have now discussed how infants are presented in addressed direct marketing sent to Swedish parents during their first year as parents. The analysis shows three dominant visual-commercial discourses that are constructed at the intersection of materiality, image and text.

The study contributes to the field of child consumption by shedding light on an understudied group of children and a neglected type of advertising that is part of the everyday life of almost all parents in the West. It gives insights into how new parents are asked to consume for their infants and how children as young as infants are made part of consumer culture. The study present how infants are positioned as central to a certain kind of consumption through direct marketing. In address and requests, children are positioned as extensions of the parents as consumers, as it is with regard to the child that the bulk of the marketed commodities are to be bought by parents. Notions and ideas of infants are stressed as reasons for consumption, showing how infants are given a direct role in relation to (increase) consumption. This shows that ideas of children are central in understanding everyday consumption and in the messages playing part in the consumer socialization of parents. As the visualizations of the age category infants, as well as of parents, are shown to be very uniform and that the marketing play on especially mothers' fear of not providing the optimal conditions for the child, the study highlights the necessity of a critical dialogue between marketers, producers, parents and other actors in the child consumer business about their respective responsibilities and needs. 
What the paper finally reveals are that the three different discourses together function as such strong claims of truth that it appears as if it is not the marketer's arguing for consumption but that it is the infants' character demanding and driving parents towards consumption. By visually showing how infants are, the direct marketing conveys the message that care, consumption and children's characters are inseparable parts of the love that parents inevitably are understood to be feeling for their own infant.

\section{References}

Bonde-Teir, M. and Westerståhl, P. (2005), Direktreklam: från idé till påverkan, Liber, Malmö.

Boulton C (2007), "Don't smile for the camera: Black power, para-proxemics and prolepsis in print ads for hip-hop clothing", International Journal of Communication, Vol. 1, No. 1, pp. 758-788.

Castaneda C (2003), Figurations: child, bodies, world, Duke University Press, Durham, NC.

Cook, D. T. (2011), "Trough mother's eyes: Ideology, the 'child' and multiple mothers in U.S American mothering magazines", Advertising and Society Review, Vol. 12, No. 2.

Cross, G. (2004a), "Wondrous innocence, print advertising and the origins of permissive child rearing in the US", Journal of Consumer Culture, Vol. 4, No. 2, pp. 183-201.

Cross, G. (2004b), The cute and the cool: Wondrous innocence and modern American children's culture, Oxford University Press, New York.

Dahlqvist, U. and Linde, M. (2009), Reklameffekter: strategi, utformning och medieval: en bok för dig som arbetar med eller vill arbeta med kommunikation och reklam, Liber, Malmö.

Davies, A. et. al. (2010a), "Motherhood, Marketization, and Consumer Vulnerability", Journal of Macromarketing, Vol. 30, No 4, pp. 384-397.

Davies. A. et. al. (2010b), "Buying into motherhood? Problematic consumption and ambivalence in transitional phases", Consumption Markets \& Culture, Vol. 13, No. 4, pp. 373-397.

Fairclough, N. (1992), Discourse and social change, Polity Press, Cambridge.

Fairclough, N. (1995), Media discourse. Arnold, London.

Goldman, R. (1992), Reading ads socially, Routledge, London.

Gram, M. (2004), "The future world champions?: Ideals for upbringing represented in contemporary European advertisements", Childhood, Vol. 11, No. 3, pp. 319-337.

Grusell, M. (2008), Reklam - en objuden gäst?: allmänhetens uppfattningar om reklam $i$ morgonpress och tv. Diss., Göteborgs universitet, Göteborg.

Halldén, G. (2007), Den moderna barndomen och barns vardagsliv, Carlssons, Stockholm.

Higonnet, A. (1998), Pictures of innocence: The history and crisis of ideal childhood, Thames \& Hudson, London.

Holland, P. (2004), Picturing childhood: The myth of the child in popular imagery, I.B. Tauris, New York.

Husz, O. and Lagerkvist, A. (2001), "Konsumtionens motsägelser", Aléx, P. and Söderberg, J. (Eds.) Förbjudna njutningar- spår från konsumtionskulturens historia i Sverige, Ekonomiskhistoriska institutionen, Stockholms Univ., Stockholm.

James, A., Jenks, C. and Prout, A. (1998), Theorizing childhood, Polity Press, London.

Jansson, A. (2002), "The Mediatization of Consumption: Towards an analytical framework of image culture", Journal of Consumer Culture, Vol. 2, No. 1, pp. 5-31. 
Jensen, J. M. (1994), Gennem lys og skygger: familiefotografier fra forrige århundrede til i dag, Systime, Herning.

Lee, N. (2001), Childhood and society: growing up in an age of uncertainty, Open University, Maidenhead.

Lupton, D. (2012), "Infant embodiment and interembodiment: A review of sociocultural perspectives", Childhood, Vol. 20, No. 1, pp. 37-50.

Mackay, H. (1997), 'Introduction", Mackay, H., Consumption and everyday life, Sage, London, pp. 1-12.

Martens, L. (2010), "The cute, the spectacle and the practical: Narratives of new parents and babies at the baby show", Buckingham, D. and Tingstad, V. (Eds.) Childhood and consumer culture, Palgrave Macmillan, Basingstoke, pp. 146-160.

McNamee, S. and Seymour, J. (2013), "Towards a sociology of 10-12 year olds? Emerging methodological issues in the "new' social studies of childhood", Childhood, Vol. 20, No. 2, pp. 156-168.

Mukerji, C. (1997), "Monsters and Muppets: The History of Childhood and Techniques of Cultural Analysis", Long, E. (Ed.) From sociology to cultural studies: new perspectives, Blackwell, Oxford.

Parsons, A. and Ballantine, P. (2008), "The gifts we buy for children", Young Consumers, Vol. 9, No. 4, pp. 308-315.

Paterson, Mark (2006), Consumption and everyday life, Routledge, London.

Prothero, A. (2006), "The F Word: The use of fear in advertising to mothers", Advertising and Society Review, Vol. 7, No. 4.

Pugh, A. J. (2005), "Selling Compromise: Toys, Motherhood, and the Cultural Deal", Gender \& Society, Vol. 19, No. 6, pp. 729-749.

Rose, G. (2007), Visual Methodologies, SAGE, London.

Schroeder, J. E. (2002), Visual Consumption, Routledge, London \& New York.

Sjöberg J (2013), I marknadens öga; barn och visuell konsumtion, Diss., Linköpings universitet, Linköping.

Sjöberg, J. (2012), "Fatherhood through direct marketing", Sparrman, A. Sandin, B. and Sjöberg, J. (Eds) Situating child consumption: Rethinking values and notions of children, childhood and consumption, Nordic Academic Press, Lund, pp. 133-155.

Sparrman, A. and Sandin, B. (2012), "Situated child consumption: An introduction", Sparrman A, Sandin, B. and Sjöberg, J. (Eds) Situating child consumption: Rethinking values and notions of children, childhood and consumption, Nordic Academic Press, Lund, pp. 9-31.

Statens Personadressregister, SPAR, available at http://www.statenspersonadressregister.se (accessed 7 Februari 2014).

Sunderland, J. (2006), "'Parenting' or 'mothering'? The case of modern childcare magazines", Discourse \& Society, Vol. 17, No. 4, pp. 503-528.

Svensson, J. (1988), Kommunikationshistoria, Studentlitteratur, Lund.

Thompson, R. and Kehily M. J. (2008), The Making of Modern Motherhood; Memories, Representations, Practices. The Open University, http://www3.open.ac.uk/events/0/200873 43860 o1.pdf.

Thomsen, T. U. and Sørensen, E. B. (2006), "The First Four-wheeled Status Symbol: Pram Consumption as a Vehicle for the Construction of Motherhood Identity", Journal of Marketing Management, Vol. 22, No. 9/10, pp. 907-927. 
Valentine, G. (1996), "Angels and devils: moral landscapes of childhood", Environment and Planning D: Society and Space, Vol. 14, No. 5, pp. 581-599.

Weaver-Hightower, M.B. (2012), "Waltzing Matilda: An Autoethnography of a Father's Stillbirth", Journal of Contemporary Ethnography, Vol. 41, No. 4, pp. 462-491.

\section{Notes}

\footnotetext{
${ }^{\mathrm{i}}$ The SPAR register is obtained by The Swedish National Tax Board.

ii The marketing sent to the three families most often contained a note stating that their address had been collected through the SPAR register. The unsolicited marketing collected and analyzed is thus sent from different companies to the families with the aid of SPAR. Companies are not allowed to search for or send unsolicited addressed direct marketing to parents with children younger than about eight weeks. The first ads received by the families in the present study arrived when the child was ten to eleven weeks. iii The addressed direct marketing the parents received during the year only very occasionally concerned something other than child consumption. The companies targeting them were not companies the parents previously had been customers at. The parents did not reply to the many requests posed by the marketing to order more information or to become members of clubs, hence the material is directly connected to the parents' new role as parents and not sought out by them at all. Many of the dispatches were opened by the parents. Sometimes they asked me to make copies of for example free samples and coupons so that they could use the originals, and on one occasion Linn asked me to save a book on children's food. Otherwise the families were uninterested to keep the received material for further use or reading.

iv Products concerning children's bodies are, for example, clothing, diapers, skincare, prams, carriers, child seats for cars, and feeding products.

${ }^{v}$ Products for play are mainly toys, but some products are both entertaining and have educational and training aims, making it not at all obvious whether baby gyms, for example, should be classified as a product for play or as a product to stimulate children's knowledge and development, the third product category.

vi The product category "knowledge" covers products that focus on learning and developing skills. It includes parent's learning about children's development and upbringing through books and magazines, but also products aimed at increasing infants' knowledge and physical, cognitive, and intellectual development, such as children's books and baby swimming classes.

vii The products in the category "memorabilia" emphasize the uniqueness of infancy, marketing products such as cameras, professional portrait photography, printed matter, and objects decorated with the child's name or hand- and footprints.

viii Products in the motherhood category cover, for example, maternity clothes, breastfeeding equipment, and prenatal vitamins.

ix John received 24 separate mailings between 2008 and 2009. All mailings were addressed to him due to his partner's choice to make herself unavailable to companies trying to access her through the Swedish SPAR register.

${ }^{\mathrm{x}}$ The number of separate mailings sent to Ulrika during 2010-2011 is unknown, as the material was handed over to the author without some of the wrappings. Both Ulrika and her male partner are accessible for companies to find in the Swedish SPAR register. However, all mailings they received were addressed to the mother Ulrika.

${ }^{x i}$ Linn received 41 separate mailings between 2011 and 2012. Both Linn and her male partner are accessible for companies to find in the Swedish SPAR register. However all mailings they received were addressed to the mother Linn.

xii In total 3072 people are seen in the material. 2056 of them are children of different ages, mostly younger than approximately two years of age.
} 